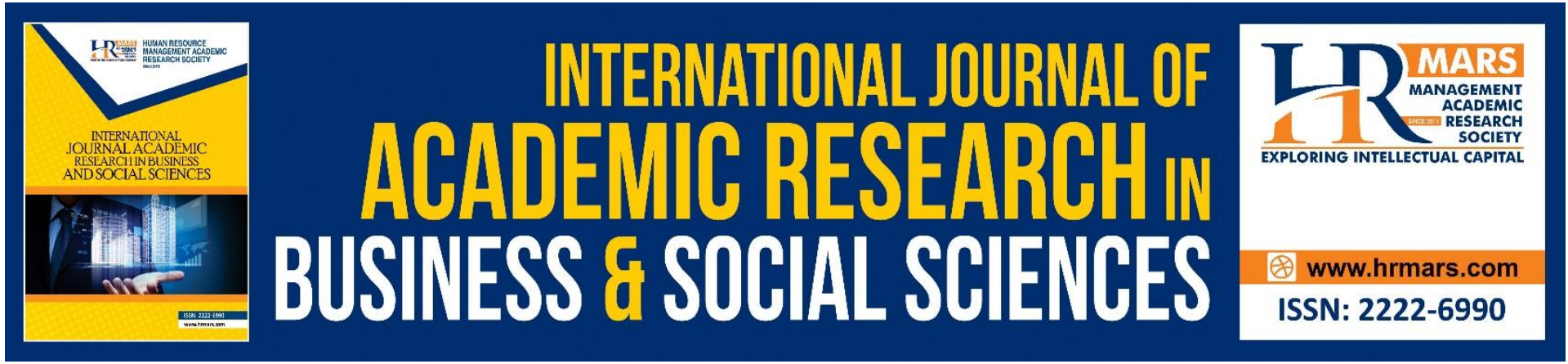

\title{
M-Heutagogy Acceptance among Students of Higher Education Institutions: The Conceptual Framework
}

\section{Analisa Hamdan, Kung-Teck Wong, Nor Syazwani Mat Salleh}

To Link this Article: http://dx.doi.org/10.6007/IJARBSS/v11-i6/10392

DOI:10.6007/IJARBSS/v11-i6/10392

Received: 20 April 2021, Revised: 23 May 2021, Accepted: 08 June 2021

Published Online: 28 June 2021

In-Text Citation: (Hamdan et al., 2021)

To Cite this Article: Hamdan, A., Wong, K.-T., \& Salleh, N. S. M. (2021). M-Heutagogy Acceptance among Students of Higher Education Institutions: The Conceptual Framework. International Journal of Academic Research in Business and Social Sciences, 11(6), 1766-1783.

\section{Copyright: @ 2021 The Author(s)}

Published by Human Resource Management Academic Research Society (www.hrmars.com)

This article is published under the Creative Commons Attribution (CC BY 4.0) license. Anyone may reproduce, distribute, translate and create derivative works of this article (for both commercial and non-commercial purposes), subject to full attribution to the original publication and authors. The full terms of this license may be seen at: http://creativecommons.org/licences/by/4.0/legalcode

Vol. 11, No. 6, 2021, Pg. 1766 - 1783

Full Terms \& Conditions of access and use can be found at http://hrmars.com/index.php/pages/detail/publication-ethics 


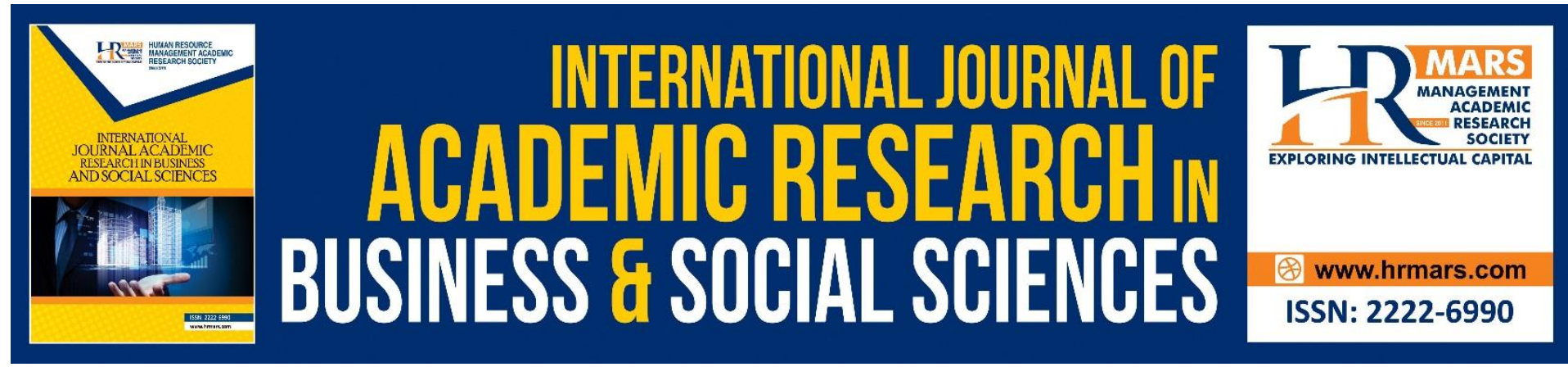

\title{
M-Heutagogy Acceptance among Students of Higher Education Institutions: The Conceptual Framework
}

\author{
Analisa Hamdan ${ }^{1}$, Kung-Teck Wong' ${ }^{2}$, Nor Syazwani Mat \\ Salleh ${ }^{3}$ \\ ${ }^{1,2}$ Faculty of Human Development, Sultan Idris Education University, Malaysia, ${ }^{3}$ Faculty of \\ Art, Computing and Creative Industry, Sultan Idris Education University, Malaysia
}

\begin{abstract}
The education systems worldwide are showing changes in teaching and learning. The Covid19 pandemic that occurred since the end of 2019 is also a contributing factor to the change in our country's education system. Students and educators have to cope with the challenges of learning out of the classroom. Therefore, one of the learning approaches, which is Mobile Heutagogy (M-Heutagogy) has been chosen by educators as a teaching and learning framework. Numerous studies have identified the effectiveness of M-Heutagogy to promote learner autonomy and capability among higher education institutions students. However, past studies have shown students mostly having problem to learn online due to weak Internet access. Hence, the main purpose of this study is to discuss the factors that influence the acceptance of M-Heutagogy. This study proposed a conceptual framework of M-Heutagogy acceptance that predicts the behavioural intentions to use M-Heutagogy among students. This study will contribute to the body of knowledge, methodology and practice in providing insights of the acceptance factors of M-Heutagogy among students of Higher Education Institutions in Malaysia.
\end{abstract}

Keywords: Heutagogy, Learner Autonomy, Conceptual Framework, Learning Style, Unified Theory of Acceptance and Use of Technology.

\section{Introduction}

Changes to technology over time has affected many aspects of life. Technological changes affect our job, education and daily task. Besides, the education system changes with the advancement of technology and time. Thus, the world's education system is also influencing drastic changes in line with state-of-the-art technological equipment. For example, the use of popular OHP projectors in the 80 s were no longer used in the 21st century. These are appliances that have been replaced with LCD projectors that are more sophisticated and effective. Similarly, the education system in the world is also changing in terms of the teaching and learning process (T\&L). In many countries over the world, the T\&L process has successfully become a teaching and facilitating process (PdPc). The implementation of PdPc has been integrated with the use of technology that has resulted in 21st-century learning. 
The higher education system in Malaysia is also not left behind to experience changes as a result of technological advances. One of the government initiatives that has been introduced and emphasized in the higher education system in Malaysia is the Future Ready curriculum (Ministry of Higher Education, 2018a). The Ministry of Higher Education (MOHE) has introduced the Malaysian Higher Education 4.0 Framework in 2018 as a continuation of the government's goals in redesigning higher education (Ministry of Higher Education, 2018b). The framework serves as a guide for all stakeholders in improving access and quality of higher education systems in the country (Ministry of Higher Education, 2018b). The framework comprises four key elements, which are: (i) Future-Ready Curriculum, (ii) Agile Governance, (iii) Talent Planning, and (iv) Research \& Innovation (Research \& Innovation). Therefore, the Future Ready curriculum is one of the four key elements that will be the major focused among educators.

Education 4.0 is an educational transformation towards Higher Education 4.0 in line with 4IR and the Malaysian Education Development Plan 2015-2025. According to former Minister of Higher Education Malaysia, Dato' Seri Idris Jusoh, Future-Ready Curriculum requires four transformations. The four transformations are (i) Re-designing the Learning Room, (ii) Flexible and Organic Curriculum, (iii) 21st Century Pedagogy (iv) Alternative Assessment (Ministry of Higher Education, 2018b). Based on the above four transformations, we can conclude that heutagogy is an appropriate and vital approach to the 4IR challenge and indirectly enhances the quality of the higher education system in Malaysia.

Heutagogy is a new concept of teaching and learning (Narayan \& Herrington, 2014). According to Hase and Kenyon (2000), heutagogy is a self-determined leaning. The term heutagogy came into existence as early as 2000 in Australia (Hase \& Kenyon, 2000). This term has become popular in educational fields. However, the term heutagogy has been interpreted and given a wide range of meanings over time. Many researchers define heutagogy as an extension of andragogy approaches. However, the definition of meaning in describing its characteristics is different because it is influenced by many other instructional factors (Blaschke, 2016). Several studies have begun to focus on heutagogy and technology to achieve educational transformation in Malaysia (Chan et al., 2019; Kamrozzaman et al., 2019; Chan et al., 2018; Yusoff et al., 2018; Ayub, 2018; Kedin et al., 2018; Malek, 2017; Wahi \& Idris, 2017). Based on the previous researches, it can be concluded that studies on heutagogy and Web 2.0 applications are being implemented at HEls nationwide lately.

Mobile Heutagogy (M-Heutagogy) is relatively a new concept of learning. The terms $M-$ Heutagogy came when academicians applied self-determined learning with any mobile applications and technologies to achieve learning objectives (Narayan \& Herrington, 2014). M-Heutagogy has been identified to promote student agency, creating curiosity to learn new skills, and capability in determining their own learning (Wong et al., 2020). Several studies have begun to focus on technology to achieve educational transformation (Chan et al., 2018; Yusoff et al., 2018; Ayub, 2018; Kedin et al., 2018; Malek, 2017; Wahi \& Idris, 2017). It can be concluded that many studies on heutagogy and Web 2.0 applications are being implemented at HEls across the country lately. However, no study has been conducted to determine the acceptance of M-Heutagogy in Malaysia. Only a study related to the heutagogy approach to mobile learning has been done by Kamrozzaman et al. (2019). M-Heutagogy has many benefits for students. Such as (i) enhancing critical thinking and reflection, (ii) boosting 
students' motivation and interest, and (iii) students being able to control their learning (Blaschke, 2018; Narayan \& Herrington, 2014). Thus, a study should be conducted on the acceptance of M-Heutagogy in Malaysia. The acceptance study of M-Heutagogy needs to be carried out thoroughly so that the first focus of the government's goals can be achieved.

\section{Literature Review}

Heutagogy is the study of self-determination that focus on learner-centred learning and students as a major agent of their learning. Heutagogy was first introduced in Australia by Hase \& Kenyon $(2000 ; 2007)$, and holistic framework was provided for the implementation of teaching and teaching informal education. A basic heutagogical framework for the implementation of life long informal learning has also been developed. Heutagogy or selfdetermined learning is rooted in andragogy and focus on student-centred learning (Blaschke, 2012; Hase \& Kenyon, 2000). Furthermore, heutagogy promotes the role of human agency in the process of teaching and learning (Hase \& Kenyon, 2007). In other words, students are free to determine their learning; how they are learned, and how they prove that they have mastered a topic with the involvement of their teachers.

Heutagogy has earned a place in technical and vocational schools, and the premier schools in several countries. Heutagogy has also been implemented in higher education institutions around the world, including Malaysia. This is evidenced by several past studies that carry out experiments and research related to heutagogy (Bhoyrub et al., 2010; Canning, 2010; Canning \& Callan, 2010; Malek, 2017). Heutagogy has been implemented in schools, colleges, and universities because of the holistic approach, such as a student-centred approach.

Besides, technological advances have made supporting the implementation of heutagogy more effective. Educational-based mobile applications such as Kahoot! Quizizz, Twitter, YouTube, etc. have been used by educators during the implementation of the heutagogy. Personal digital technologies are being steadily introduced into mobile learning contexts. Smartphones, tablets, and computers have attracted students to learn and facilitate the implementation of heutagogy among educators. These technological tools have been identified to give benefits to students and educators (Sung et al., 2016; Laru et al., 2014). Technological advancements such as the Internet, social medias, and MOOC have led to increasing of interest in heutagogy, as new technologies are in line with heutagogy approach (Anderson, 2010; Cochrane \& Bateman, 2009; Blaschke, 2012; Anders, 2015). The technology available in the market can meet the requirements of heutagogy design. Heutagogy design are divided into six elements namely, (i) explore, (ii) create, (iii) collaborate, (iv) connect (v) share, and (vi) reflect (Blaschke \& Hase, 2016).

M-Heutagogy has been identified to be extended to the heutagogy approach (Wong et al., 2020). M-Heutagogy is suitable for 21st-century learning and in line with Education 4.0. Besides, M-Heutagogy has been identified to promote learner-centred approach and learner autonomy. This means that M-Heutagogy emphasizes learners rather than instructors, where the instructor will act as guidance in the teaching and learning process. The use of technologies in teaching and learning or m-learning has been proven as an essential element in M-Heutagogy due to its effectiveness (Wong et al., 2018). Therefore, M-Heutagogy can be considered as a holistic learning approach that focuses on the learner, self-determined learning, and digital technology. 


\section{A Proposed Conceptual Framework}

The Unified Theory of Acceptance and Use of Technology (UTAUT) is the primary integrated theory that underlies in the acceptance study. UTAUT is selected after various studies are conducted on the models of technology acceptance to form the concept of the study. UTAUT result from a combination of eight types of theory and technology acceptance model (Venkatesh et al., 2003; Venkatesh et al., 2012). UTAUT can explain more than 70 percent of the variance in behavioural intention (Venkatesh et al., 2003). Thus, UTAUT has been selected as the underlying theory for the conceptual framework.

Moreover, M-Heutagogy comprise of self-determined learning and technological characteristics (the use of mobile technologies and Web 2.0 applications); hence UTAUT is still relevant to be chosen as the acceptance model in this study even though M-Heutagogy is considered an approach in learning. M-Heutagogy is similar to blended learning and $\mathrm{m}$ learning as students can learn anywhere and anytime using mobile technologies such as laptop, smartphones, tablets and iPad. Past studies show that research that focuses on blended learning, m-learning, digital learning and any technological-based learning and learning approaches has applied UTAUT as their main acceptance model (Aliaño et al., 2019; Kim \& Lee, 2020; Kamrozzaman et al., 2019; Persada et al., 2019; Hamdan et al., 2015; Pynoo et al., 2011). One of the latest studies on the adoption of ICT-based instruction among teachers has used the UTAUT model as their primary model (Kim \& Lee, 2020). Therefore, UTAUT will be chosen as a primary acceptance model for this study.

Besides, the UTAUT variables are capable of representing the determinant factors of $\mathrm{M}$ Heutagogy that are built based on the research questions. It means that UTAUT can be said to be comprehensive that seeks to examine the acceptance and behavioural intention of $\mathrm{M}$ Heutagogy among undergraduate students. A finding study from Kamrozzaman et al. (2019) that focus on the acceptance of m-learning with heutagogy approach shows that UTAUT variables are suitable to explain students' perception on heutagogy approach and design.

\section{Gender}

Past studies show a variety of information about gender. According to Venkatesh et al. (2003), male users tend to be more comfortable with new information systems than female users. Male users tend to spend more time using a new information system, thus obtaining benefits from the systems (Venkatesh \& Davis, 2000). Besides, Gefen and Straub (1997) claimed that gender has a significant difference with intention using a technology. For example, women might view the email in social presence more than men. However, in their study, gender has no difference in the usage of technology. This means that gender-differentiated at the level of intention but not on the usage. Gefen and Straub's (1997) view has been supported by Zandi et al (2013), and Othman et al (2011), who found that gender has a significant difference in behavioural intention. It can be concluded that gender has a significant difference in behavioural intention.

In contrast with Zandi et al (2013); Othman et al (2011), Phang et al (2006) in their studies has examined the relationship between gender and $\mathrm{BI}$ to determine the factors of information system acceptance among senior citizens. It is found that gender has no relationship with BI. Healy (2017) discusses in detail gender achievement gaps in MOOC and found that there are no gender differences between male and female students. It is because each gender needs to enrol in MOOC, especially the course that has learning evaluation by their instructors. Therefore, there is no gender discrepancy in that study. Hence, an exploration of gender 
differences may also provide more insights in response to students' intention to use the MHeutagogy approach in the future. Based on the above discussion, gender is proposed to moderate the relationship between predictive factors and Behavioural Intention.

\section{Age}

Age has received relatively little attention in the literature on technology acceptance (Venkatesh et al., 2003; Wang \& Shih, 2009). The UTAUT's original model viewed age, experience, gender and voluntariness as moderators. Age also poses as an antecedent to the beliefs about acceptance of technology based on the literature. Venkatesh et al (2003) integrate age as a moderator and found that the behaviour of consumers depends on age and gender. Past studies show that older consumers tend to face more difficulty in processing new or complex information, thus affecting their learning of new technologies (Puspitasari et al., 2019; Plude \& Hoyer, 1986). It means that the older a person is, the slower it will be to learn the system and the younger people will understand the use of the system. Besides, there was a study that clearly show there are differences in perceptions in terms of e-government use between more mature users (categorised as Generation X) and more youthful users (categorised as Generation Y) (Wang \& Shih, 2009). Thus, age is vital to be examine its moderating effects with predictive factors and $\mathrm{BI}$ to obtain more information about $\mathrm{Y}$ and $\mathrm{Z}$ generations.

In contrast, past studies show that there is a conflict of findings on age as a moderator. A past study has obtained an inverse result of predictive factors and age. The presence of an inverse relationship between age and performance expectancy, as well as the effort expectancy and the perceived gratification variable, without finding significant differences as far as the user's perception are concerned according to age concerning the facilitating conditions and the behavioural intention (Aliaño et al., 2019).

Some studies, however, remove age as a moderator. Ali and Arshad (2016) removed the age moderator as they studied the same group age of learners while conducting m-learning's acceptance study. Moreover, a study from Persada et al (2019) omit age as a moderator to find a more general view on Generation $Z$ and their behaviour towards D-learning. As this study will identify significant differences between $Y$ and $Z$ generation students, therefore the moderating effect of age should be examined further between predictive factors and behavioural intention of M-Heutagogy.

\section{Level of Education}

Turker and Selcuk (2009) claimed that education level influences the entrepreneurial intention among university students. This is in line with the Xuan et al (2020) study that also claimed the level of education had influenced the entrepreneurial intention among HEls students. It means that the education level of students has affected the entrepreneurial intention among students. However, based on past reviews, a high level of education might not affect the acceptance of technology or technology-based approach (Surjanti et al., 2019; Sánchez-Torres et al., 2017). Besides, Nguyen's (2018) study on entrepreneurial intention of Vietnamese business students confirm that level of education has no significant difference on entrepreneurial intention of business students. As there is no significant difference between education levels and entrepreneurial intention, it is reasonable to see that education will help 
a person explore new opportunities. Still, it does not automatically decide whether he or she can create a new business to take advantage of the opportunity.

Accordingly, the study expects differences level of education in terms of performance expectancy, effort expectancy, social influence, facilitating condition, learner autonomy, and learning styles with the behaviour intention of M-Heutagogy. Hence, there is a need to study the moderator effect of level of education towards behavioural intention whether there will be or not a significant difference between predictive factors and behavioural intention; in order to get in-depth insight related to M-Heutagogy's intention among undergraduate students.

\section{Experience}

The experience reflects an opportunity to use a target technology and is commonly operationalized as the passage of time from the first use of technology by an individual (Venkatesh et al., 2003). Experience is one of the moderators that affects predictive factors and behavioural intention. Past studies show experience moderated effort expectancy, social influence, and facilitating conditions (Venkatesh et al., 2003).

Besides, past studies show that experienced teachers hesitant to implement educational technology in schools, while student-teachers and newly qualified teachers are more confident users of educational technology (Galanouli \& McNair, 2001; Madden et al., 2005; Sime \& Priestley, 2005; Andersson, 2006). In line with the statement, Efe's (2011) study shows that Science student-teachers who were more experienced with educational technology had greater intentions of using the technology. However, Teo and Noyes (2011) claimed that most of the student-teachers possess little or no experience in using computers when posting in the actual school. Wong and Teo (2009) suggest that it is advisable to examine the behavioural intention among student-teachers rather than actual usage of a new technology-based approach based on students' experiences.

The study expects differences experience in terms of performance expectancy, effort expectancy, social influence, facilitating condition, learner autonomy, and learning styles with the behaviour intention of $\mathrm{M}$-Heutagogy. Hence, there is a need to study the moderator effect of experience towards behavioural intention whether there will be or not a significant difference between predictive factors and behavioural intention; to get in-depth insight related to M-Heutagogy's intention among undergraduate students. Thus, the experience should be examining its moderating effect between the six predictive factors and behavioural intention.

\section{Performance Expectancy}

Performance expectancy (PE) is one of four direct determinants of the UTAUT model related to how individuals believe new technologies will help them perform better (Venkatesh et al., 2003). The term Performance Expectancy (PE) was introduced by Venkatesh et al (2003) in defining perceptions of performance acceptance as the degree or extent to which individuals believe in using a technology system to achieve their advantage or help improve their work performance. In this study, Performance Expectancy (PE) referred to as the degree to which the students' confidence in applying the M-Heutagogy approach that can help them to achieve their learning goals. These factors or constructs are extracted and determined based 
on the M-Heutagogy attributes and the six constructs of previous acceptance theories namely; Performance Expectancy (UTAUTs), Perceived Usefulness (TAMs), Extrinsic Motivation (MM), Job-fit (MPCU), Relative Advantage (IDT), and Outcome Expectation (SCT).

In teaching and learning process, students and teachers have set an expectation that the use of the technology will enhance their effectiveness and performance (Alharbi \& Drew, 2014; Alghanmi, 2014). Thus, research findings from Alharbi and Drew (2014) and Thomas et al. (2013) have shown that student expectations are the key determinant of an intention to use technology in their learning. The purpose of this study is to determine whether Performance Expectancy (PE) influenced Behavioural Intention (BI) to use M-Heutagogy. In this study, Performance Expectancy (PE) has been identified to have a significant effect on the behavioural intention to use M-Heutagogy. Through the hypothesis (H1), PE will have a significant relationship with Behavioural Intention.

Based on the significant influence of the Performance Expectancy (PE) construct and was one of the dominant constructs in most previous empirical studies (Khechine et al., 2014; Tan, 2013; Thomas et al., 2013; Venkatesh et al., 2003; Venkatesh et al., 2012), this study has defined the Performance Expectancy (PE) construct as mediator variable to identify the effect.

Performance Expectancy (PE) is a strong predictor of behavioural intentions, but Performance Expectancy (PE) is also moderately impacted by gender and age moderators. PE has been claimed to have a stronger impact on young men and workers (Venkatesh et al., 2003). Thus, Performance Expectancy (PE) is expected to be moderated by gender, age, level of education and experience in the context of this study and the effects of each moderator will be evaluated as a set of hypotheses.

\section{Effort Expectancy}

The Effort Expectancy (EE) is the degree of easiness or difficulties associated with using the system (Venkatesh et al., 2003). EE is an essential determinant of the behavioural intention and use of a system (Venkatesh et al., 2003). Gender, age, and experience are moderators of $\mathrm{EE}$ as these direct effects are stronger on women, older workers, and those with limited experience (Venkatesh et al., 2003).

Based on the studies of Fidani and Idrizi (2012); Birch and Irvine (2009), the determinants of EE showed no significant effect on behavioural intention. However, a study by Nassuora (2012) showed that EE has a significant and positive effect on behavioural intention. It can be concluded that acceptance studies using the UTAUT model have inconsistent findings related to the influence of EE on behavioural intention. However, in this study, EE was predicted to have a positive or significantly positive effect on behavioural intention. Through the hypothesis ( $\mathrm{H} 2)$, EE will have a significant relationship with BI.

\section{Social Influence}

The Social Influence (SI) as the extent to which individuals believe that those who are interested in the individual need to adopt the new system (Venkatesh et al., 2003). This idea of $\mathrm{SI}$ is very similar to the subjective norms of the MPCU, DOI, TAM2, and TPB-TAM models. Similarly, moderators of age, gender, experience, and voluntary use have influenced 
behavioural intentions. Based on previous studies, these moderators showed stronger effects in women and those with experience in compulsory situations (Venkatesh et al., 2003).

The studies of Birch and Irvine (2009) and Nassuora (2012) show that SI does not significantly affect behavioural intention. However, the study of Esteva-Armida and Rubio-Sanchez (2012), Fidani and Idrizi (2012), and Lai, Lai, and Jordan (2009) showed the opposite result in which SI influences behavioural intention positively and significant. There is an inconsistent effect of SI on behavioural intention, but this inconsistent finding depends on the field being studied. In this study, SI was hypothesized to exert a significant and positive influence on the behavioural intention of M-Heutagogy. Through hypothesis (H3), SI positively influences the behavioural intention.

\section{Facilitating Condition}

Facilitating Condition (FC) refers to the user's perception of the resources and support that are available to implement a behaviour (Venkatesh et al., 2003). FC in the digital technology era can now be represented by a spectrum of Information and Communication Technologies (ICT) facilities, technical support, learning environments, technology systems, and usage etiquette (Fu, 2013; Hung, 2015). In other words, FC is a matter of preparation or planning of technology design or organizational environment to eliminate barriers and constraints to the use of a technology system. Venkatesh et al (2003) defined FC as the degree of individual trust in accepting and using technology, gaining support and assistance from organizations. Elements such as technology (physical and scientific) resources, technical support, prior knowledge, and organizational assistance can explain this construct.

FC is also evaluated as an environment that helps individual or users to overcome external barriers to adopting new technologies (Venkatesh et al., 2003; Zhang et al., 2016). In this study, the FC refers to students' perceptions of physical facilities available (ICT related) such as the quality of the system, technical resources, and support available to help them in applying $\mathrm{M}$-Heutagogy. This construct was extracted based on the attributes of the $\mathrm{M}$ Heutagogy and the combination of Facilitating Conditions (UTAUT), Perceived Behaviour Control (C-TAM-TPB), Compatibility (IDT), and Perceived Control (TPB).

\section{Learner Autonomy}

Learner autonomy refers to the ability of the students to have adequate and enough responsibility for their learning process through mobile learning and mobile devices (Yeap et al., 2016). Students will take full responsibility to lead their learning from defining the learning objectives until they get their learning outcomes. Leaner autonomy focuses more on a student-centred approach, where students in charge of their own learning. Reviews from past studies show that the learner autonomy variable has been widely studied for the past few years, especially in the field of language. Some researches study the Learner Autonomy variable and the relationship with students' academic performance. Learner Autonomy has shown a significant relationship between the Learner Autonomy Profile score and students' academic performance (Ng et al., 2011). This means that when students have been given autonomy to conduct their learning, their academic performance will arise. This view is supported by Stoszkowski and McCarthy's (2018) study finding that show learner autonomy and heutagogy is valued by the students that get excellent achievements in studies. 
Wong et al. (2018) claimed that learner autonomy has a positive effect on the blended learning approach rather than conventional learning. Blended learning is an approach that integrates pedagogical methods with the use of technologies. Therefore, blended learning has successfully influenced the students in charge of their learning as well as showing excellent performance in studies. In the context of this study, Learner Autonomy construct refers to the student's ability to take charge and determined their learning, activities, and assessments based on their learning styles preferences and mobile applications of their choices. Therefore, the study has established hypotheses to determine the direct effect of Learner Autonomy on an endogenous variable which is Behavioural Intention (BI) to explain the acceptance of M-Heutagogy approach.

\section{Learning Style}

Learning Style (LS) refers to students' typical manner to attend, process, and acquire information, knowledge or new experience in the context of educational psychology (Mok, 2008, pg. 234). Besides, Learning Style can also be defined as a perception made by individuals to develop a concept in cognitive psychology (Mok, 2008). It means that learning styles can be defined differently based on different perspective or fields. Learning styles can be grouped based on the focus fields. According to Reid (2005), learning styles can be grouped based on (i) personality styles, (ii) environmental influences in learning, (iii) cognitive styles, and (iv) metacognitive influences. Learning Styles can also be mediated by several factors such as (i) culture, (ii) school climate, (iii) expectations, (iv) teaching styles, and (v) classroom practices (Reid, 2005). Although students' learning styles can be influenced by mediating factors, however, learning styles has been identified to influence the mediating factors. Therefore, it can be concluded that Learning Style and the mediator variables are flexible as learning is a fluid process (Reid, 2005).

In the context of this study, learning style is referred to how a student learns an idea or concept while applying M-Heutagogy approach. There are many learning styles that are wellknown, such as Myers-Briggs Type Indicator (Myers et al., 1998), Multiple Intelligences (Gardner, 1995), Kolb's Learning Styles Theory (Kolb, 1984), Felder and Silverman (1988) Index of Learning Styles, and Honey and Mumford's Learning Styles Questionnaire (Van Zwanenberg et al., 2000), VARK (Fleming, 1995), and Dunn (1990). However, there are two learning style models that are frequently used in Malaysia which are, Dunn \& Dunn learning style and VARK learning style (Abu et al., 2007). Although there have been many learning styles introduced, VARK learning styles have been chosen in this study.

VARK learning styles have been chosen due to its four types of learning styles, which are (i) visual, (ii) auditory, (iii) read/write, and (iv) kinaesthetic (Fleming, 2012). The four types of learning styles are suitable to be studied as the learning styles represent the HEls' students. However, the VARK instrument will be adopted and adapted to suit the organisational and culture of HEls in Malaysia.

Huang et al. (2012) suggested that Learning Styles can be a moderator instead of being an independent variable. The reason given was students learn differently. Therefore, technologies should be provided based on learning styles so that it will cater all different learning styles. This view has been supported by Cruz et al. (2014) who claimed that there is 
an influence of Learning Style as a moderator. However, in this study, Learning Styles will not be tested as a moderator, instead of as a new independent variable.

Weng et al. (2019) claimed that Learning Styles affected the learning preference and further affected the learning outcomes and attitude. It means that teachers should change the course content and teaching mode based on the learning objectives. Their study is different from the acceptance study as it is an experimental study, but the questionnaire form has also been given to the respondents. Thus, this study will test Learning Styles variable as a determinant predictor towards Behavioural Intention.

\section{Behavioural Intention}

Behavioural Intention (BI) refers to the user's intention to perform any behaviour. Generally, people will intend to do behaviour if the behaviour has motivated them. Ajzen (1991) claimed that the stronger the intention of people to perform a behaviour, more likely they would do the behaviour. Past literature proves that there are positive relationships between behavioural intention and the actual usage of technology (Ernst et al., 2013; Fianu et al., 2018; Harsono \& Suryana, 2014; Lu \& Yang, 2014; Nair, Ali \& Leong, 2015). However, in this study, the relationship between Behavioural Intention (BI) and actual usage will not be examined.

In this study, $\mathrm{BI}$ refers to the undergraduate students' intention to use $\mathrm{M}$-Heutagogy. $\mathrm{BI}$ is used to describe the level of acceptance or desire of users to use M-Heutagogy. The results could be used by the stakeholders to upgrade their institutions, and teaching approaches to its best in order to attract more and more students to register in their universities. However, one major drawback of the acceptance study is that there are so many different determinants variables for each study, and the items for behavioural intentions are not the same. This means that there was no consistency with the determinant's variables used in one study. Besides, the number of items in $\mathrm{Bl}$ is different. In conclusion, the study acceptance should be done based on the advantages to the stakeholders in order to upgrade and provide better teaching and learning approaches.

Based on previous study, the relationship between independent variables with $\mathrm{BI}$ has been examined. Past literature shows that there are numbers of variables that have positive effect or relationship with $\mathrm{BI}$ such as PU, PEOU, ATT, and FC (Alraimi et al., 2015; Kumar \& Chaudhary, 2017; Wu \& Chen, 2016; Yeap et al., 2016). Nordin et al. (2015) claimed that FC is one of the prominent determinants to $\mathrm{BI}$ besides performance expectancy and effort expectancy. It is due to the pre-recorded teaching videos where the instructors were present in the lectures as 'talking-heads' (Adams et al., 2014; Nordin et al., 2015). The teaching and learning resources together with the easily downloadable videos, are influencing the students to learn and enrol in MOOC. That means FC has successfully influenced the intention of the students to enrol in MOOC. However, there is no study that examine relationship between predictive factors and behavioural intention to use M-Heutagogy. Therefore, this study will examine the relationship between predictors towards Behavioural Intention.

\section{The Conceptual Framework}

The conceptual framework of this study is based on explanations of the theory, model, and philosophy used. Whenever a researcher seeks to understand the process by which two variables are related, a mediating variable is relevant. Therefore, this study will examine the 
effect of mediator variables. Besides, moderating variables are vital whenever a researcher needs to assess whether two variables have the same relation across groups. Hence, moderator variables such as gender, age, level of education and experience will be examined its moderating effects in this study. This study's framework illustrates the proposed relationship between the dependent variable and the dependent variable with moderator variables and mediator variables. To provide a clearer picture of the hypothesis of the study on the relationship between the tested variables, the study hypothesis is presented graphically through the study framework as shown in Figure 1. The proposed conceptual framework.

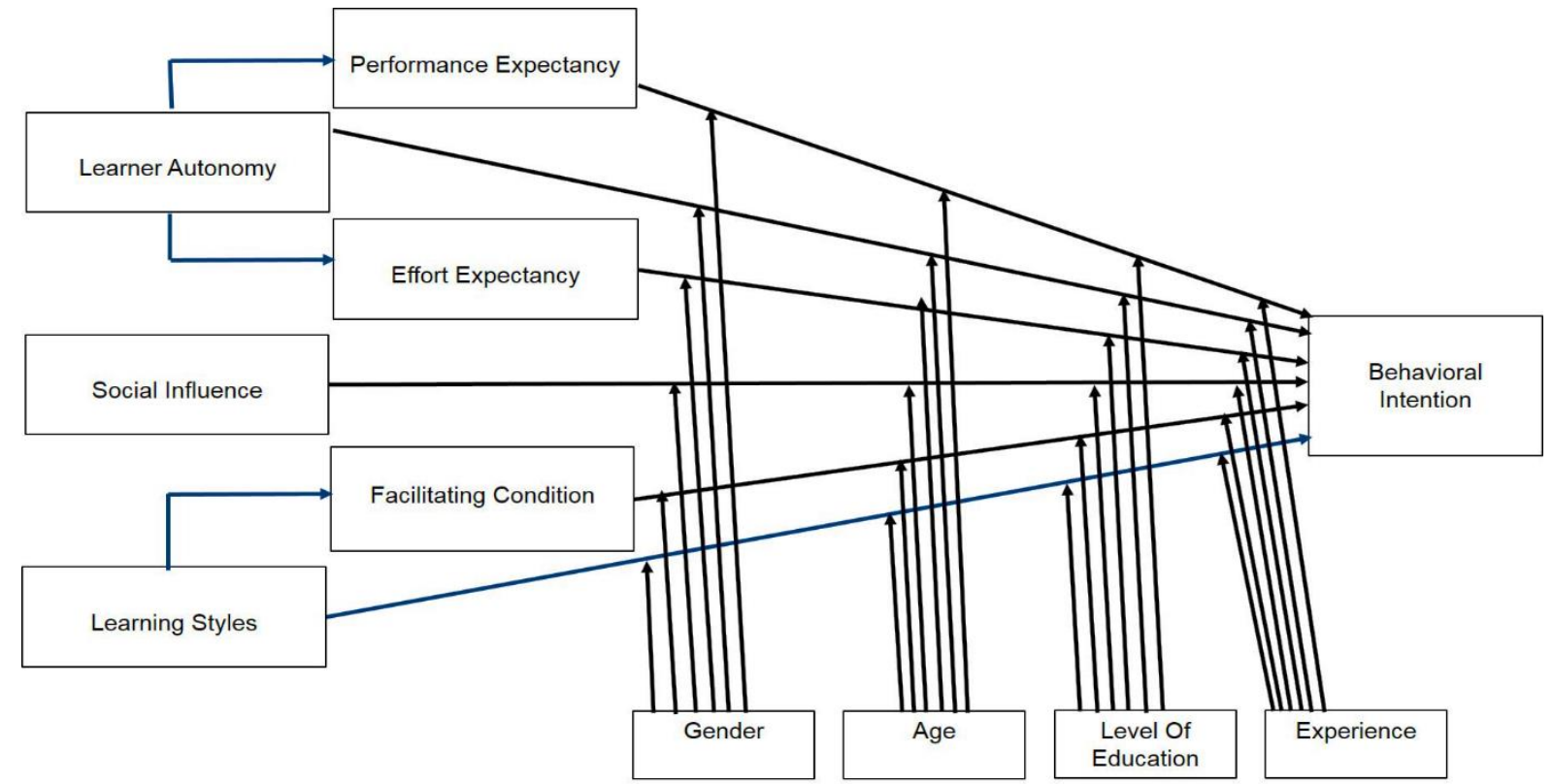

Figure 1. The proposed conceptual framework

\section{Conclusion}

In conclusion, this concept paper has discussed the advantages and factors that have led to the integration of two constructs closely related to heutagogy in the higher education environment in Malaysia. Through this concept paper, the conceptual framework of $\mathrm{M}$ Heutagogy acceptance has been proposed based on the Unified Theory of Acceptance and Use of Technology with the constructs of learner autonomy and learning style that have been stated. This proposed conceptual framework is a guide and ideas that can be referred to examine factors that influence the acceptance of M-Heutagogy among students. Nevertheless, further studies need to be conducted to prove the effectiveness of this conceptual framework.

\section{Corresponding Author}

Associate Professor Ts. Dr Wong Kung Teck

Faculty of Human Development Sultan Idris Education University, Malaysia

Email: thomas@fpm.upsi.edu.my

\section{References}

Abu, B., Johan, O. M., Mansor, S. M. S. S., \& Jaafar, H. (2007). Kepelbagaian Gaya Pembelajaran Dan Kemahiran Belajar Pelajar Universiti Di Fakulti Pendidikan, UTM Johor. No. Vot Penyelidikan, 71881. 
Adams, C., Yin, Y., Vargas Madriz, L. F., \& Mullen, C. S. (2014). A phenomenology of learning large: The tutorial sphere of XMOOC video lectures. Distance Education, 35(2), 202216.

Ajzen, I. (1991). The theory of planned behavior. Organizational Behavior and Human Decision Processes, 50(2), 179-211.

Alghanmi, S. (2014). Investigating the interpersonal and contextual factors govern Saudi lecturers' motivation in creating innovative blended learning environment that web 2.0-based. Turkish Online Journal of Educational Technology, 13(3), 96-106.

Alharbi, S., \& Drew, S. (2014). Using the technology acceptance model in understanding academics' behavioural intention to use learning management systems. International Journal of Advanced Computer Science and Applications, 5(1), 143-155.

Ali, R. A., \& Arshad, M. R. M. (2016). Perspectives of students' behavior towards mobile learning (M-learning) in Egypt: an extension of the UTAUT model. Engineering, Technology \& Applied Science Research, 6(4), 1109-1114.

Aliaño, Á. M., Hueros, A. D., Franco, M. G., \& Aguaded, I. (2019). Mobile learning in university contexts based on the unified theory of acceptance and use of technology (UTAUT). Journal of New Approaches in Educational Research (NAER Journal), 8(1), 717.

Alraimi, K. M., Zo, H., \& Ciganek, A. P. (2015). Understanding the MOOCs continuance: The role of openness and reputation. Computers \& Education, 80, 28-38.

Anders, A. (2015). Theories and applications of massive online open courses (MOOCs): The case for hybrid design. The International Review of Research in Open and Distributed Learning, 16(6).

Anderson, T. (2010). Theories for learning with emerging technologies. Emergence and innovation in digital learning: Foundations and applications, 23-39.

Andersson, S. B. (2006). Newly qualified teachers' learning related to their use of information and communication technology: a Swedish perspective. British Journal of Educatioanl Technology, 37, 665-682.

Ayub, E. (2018). Topic: A smart future classroom in VLE for a massive number of students: a solution for instructor and classroom shortages. University Carnival On E-Learning (IUCEL) 2018, 93.

Bhoyrub, J., Hurley, J., Neilson, G. R., Ramsay, M., \& Smith, M. (2010). Heutagogy: An alternative practice-based learning approach. Nurse education in practice, 10(6), 322326.

Birch, A., \& Irvine, V. (2009). Preservice teachers' acceptance of ICT integration in the classroom: applying the UTAUT model. Educational media international, 46(4), 295315.

Blaschke, L. M. (2012). Heutagogy and lifelong learning: A review of heutagogical practice and self-determined learning. The International Review of Research in Open and Distance Learning (IRRODL), 13(1), 56-71.

Blaschke, L. M. (2016). Strategies for implementing self-determined learning (heutagogy) within education: A comparison of three institutions (Australia, South Africa, and Israel). Unpublished master's thesis, Carl von Ossietzky Universität Oldenburg, Oldenburg, Germany.

Blaschke, L. M. (2018). Self-determined learning (heutagogy) and digital media creating integrated educational environments for developing lifelong learning skills. In The Digital Turn in Higher Education (pp. 129-140). Springer VS, Wiesbaden. 
Blaschke, L. M., \& Hase, S. (2016). Heutagogy: A holistic framework for creating twenty-firstcentury self-determined learners. In The future of ubiquitous learning (pp. 25-40). Springer, Berlin, Heidelberg.

Canning, N. (2010). Playing with heutagogy: Exploring strategies to empower mature learners in higher education. Journal of further and Higher Education, 34(1), 59-71.

Canning, N., \& Callan, S. (2010). Heutagogy: Spirals of reflection to empower learners in higher education. Reflective Practice, 11(1), 71-82.

Chan, C. G., Embi, M. A., \& Hashim, H. (2019). Primary school teachers' readiness towards heutagogy and peeragogy. Asian Education Studies, 4(1), 11-21.

Chan, C. S. C. Leng, P. G., Saidon Z. L., \& Lim, C. K. (2018). Empowering Youth Performance of the Living Multicultural Heritage of Tanjong Malim through a Heutagogical Approach. In Mohd Kipli, A. R., Chan, C.S.C., Saidon, Z. L., S., Augustine, C. \& Maniam, S. (Eds.), Proceedings of the 3rd International Music and Performing Arts Conference (pp. 37-45). Tanjong Malim: Faculty of Music and Performing Arts, Universiti Pendidikan Sultan Idris, Malaysia.

Cochrane, T., \& Bateman, R. (2009). Transforming pedagogy using mobile Web 2.0. International Journal of Mobile and Blended Learning (IJMBL), 1(4), 56-83.

Cruz, Y., Boughzala, I., \& Assar, S. (2014). Technology acceptance and actual use with mobile learning: first stage for studying the influence of learning styles on the behavioral intention.

Dunn, R. (1990). Understanding the Dunn and Dunn learning styles model and the need for individual diagnosis and prescription. Reading, Writing, and Learning Disabilities, 6(3), 223-247.

Efe, R. (2011). Science Student Teachers and Educational Technology: Experience, Intentions, and Value. Educational technology \& society, 14(1), 228-240.

Ernst, C. P. H., Pfeiffer, J., \& Rothlauf, F. (2013). Hedonic and utilitarian motivations of social network site adoption. Johannes Gutenberg University Mainz: Working Papers in Information Systems and Business Administration.

Esteva-Armida, E., \& Rubio-Sanchez, A. (2012). Adoption process for VolP: The UTAUT model. International Journal of E-Services and Mobile Applications (IJESMA), 4(4), 1531.

Felder, R. M., \& Silverman, L. K. (1988). Learning and teaching styles in engineering education. Engineering education, 78(7), 674-681.

Fianu, E., Blewett, C., Ampong, G., \& Ofori, K. (2018). Factors Affecting MOOC Usage by Students in Selected Ghanaian Universities. Education Sciences, 8(2), 70.

Fidani, A., \& Idrizi, F. (2012). Investigating students' acceptance of a learning management system in university education: a structural equation modeling approach. ICT Innovations 2012 Web Proceedings, 2(23), 311-320.

Fleming, N. D. (1995). I'm different; not dumb. Modes of presentation (VARK) in the tertiary classroom. In Research and development in higher education, Proceedings of the 1995 Annual Conference of the Higher Education and Research Development Society of Australasia (HERDSA), HERDSA (Vol. 18, pp. 308-313).

Fleming, N. D. (2012). Facts, fallacies and myths: VARK and learning preferences. Retrieved from vark-learn. com/Introduction-to-vark/the-vark-modalities.

$\mathrm{Fu}$, J. (2013). ICT in education: A critical literature review and its implications. International Journal of Education and Development using information and Communication Technology (IJEDICT), 9(1), 112-125. 
Galanouli, D., \& McNair, V. (2001). Students' perceptions of ICT- related support in teaching placements. Journal of Computer Assisted Learning, 17, 396-408.

Gardner, H. (1995). Reflections on multiple intelligences: Myths and messages. Phi Delta Kappan, 77(3), 200.

Gefen, D., \& Straub, D. W. (1997). Gender differences in the perception and use of e-mail: An extension to the technology acceptance model. MIS quarterly, 389-400.

Hamdan, A., Din, R., Manaf, S. Z. A., Salleh, N. S. M., Kamsin, I. F., Ismail, N. M. (2015). Pengaplikasian UTAUT Dalam Bidang Pendidikan: Satu Ulasan Sistematik (UTAUT Applications in the field of Education: A Systematic Review). Journal of Advanced Review on Scientific Research/ Vol, 5(1), 10-29.

Harsono, I. L. D., \& Suryana, L. A. (2014). Factors Affecting the Use Behavior of Social Media Using UTAUT 2 Model. Proceedings of the First Asia-Pacific Conference on Global Business, Economic, Finance and Social Science. Retrieved from http://globalbizresearch.org/Singapore_Conference/pdf/pdf/S471.pdf

Hase, S., \& Kenyon, C. (2000). From andragogy to heutagogy. Ulti-BASE In-Site.

Hase, S., \& Kenyon, C. (2007). Heutagogy: A child of complexity theory. Complicity: An international journal of complexity and education, 4(1).

Healy, P. A. (2017). Georgetown's first six MOOCs: Completion, intention, and gender achievement gaps. Undergraduate Economic Review, 14(1),1

Huang, E. Y., Lin, S. W., \& Huang, T. K. (2012). What type of learning style leads to online participation in the mixed-mode e-learning environment? A study of software usage instruction. Computers \& Education, 58(1). 338-349.

Hung, M. (2015). Teacher readiness for online learning: Scale development and teacher perception. Computers \& Education, 94, 120-133.

http://doi.org/10.1016/j.compedu.2015.11.012

Kamrozzaman, N. A., Badusah, J. \& Mohammad, W. M. R. W. (2019). Heutagogy Approach: Effectiveness of M-Learning for Lifelong Learning Education, Sains Humanika, 11(3), 5361.

Kedin, N. A., Sulaiman, S. B., Saari, I. S., Ab Hamid, A. S., \& Zahidi, N. E. (2018). ID NO. UiTM006 TOPIC:"Heutagogy Approach: Exploring Statistics in MOOC. UNIVERSITY CARNIVAL on e-LEARNING (IUCEL) 2018, 148.

Khechine, H., Lakhal, S., Pascot, D., \& Bytha, A. (2014). UTAUT model for blended learning: The role of gender and age in the intention to use webinars. Interdisciplinary Journal of E-Learning and Learning Objects, 10(1), 33-52.

Kim, J., \& Lee, K. S. S. (2020). Conceptual model to predict Filipino teachers' adoption of ICTbased instruction in class: using the UTAUT model. Asia Pacific Journal of Education, 115.

Kolb, D. A. (1984). Experiential learning: Experience as the source of learning and development. FT press.

Kumar, P., \& Chaudhary, S. (2017). Massive open online courses and modern education. International Journal of Education and Management Studies, 7(3), 422-424.

Lai, D. C. F., Lai, I. K. W., \& Jordan, E. (2009). An extended UTAUT model for the study of negative user adoption behaviours of mobile commerce. In Proceedings of the Ninth International Conference on Electronic Business.

Laru, J., Näykki, P., \& Järvelä, S. (2014). Four stages of research on the educational use of ubiquitous computing. IEEE Transactions on Learning Technologies, 8(1), 69-82. 
Lu, H. P., \& Yang, Y. W. (2014). Toward an understanding of the behavioral intention to use a social networking site: An extension of task-technology fit to social technology fit. Computers in Human Behavior, 34, 323-332.

Madden, A., Ford, N., Miller, D., \& Levy, P. (2005). Using the Internet in teaching: the views of practitioners (A survey of views of secondary school teachers in Sheffield, UK). British Journal of Educational Technology, 36, 255-280.

Malek, J. A. (2017). The impact of heutagogy education through telecentre in smart village (SV). e-Bangi, 14(2).

Ministry of Higher Education. (2018a). Amanat Menteri Pendidikan Tinggi 2018. Putrajaya: Kementerian Pendidikan Malaysia.

Ministry of Higher Education. (2018b). Framing Malaysia Higher Education 4.0: Future-proof talents. Putrajaya: Kementerian Pendidikan Tinggi Malaysia.

Mok, S. S. (2008). Educational psychology \& pedagogy: Learner and learning environment. Penerbitan Multimedia.

Myers, I. B., McCaulley, M. H., Quenk, N. L., \& Hammer, A. L. (1998). MBTI manual: A guide to the development and use of the Myers-Briggs Type Indicator (Vol. 3). Palo Alto, CA: Consulting Psychologists Press.

Nair, P. K., Ali, F., \& Leong, L. C. (2015). Factors affecting acceptance \& use of ReWIND: Validating the extended unified theory of acceptance and use of technology. Interactive Technology and Smart Education, 12(3), 183-201.

Narayan, V., \& Herrington, J. (2014). Towards a theoretical mobile heutagogy framework. Paper presented at ASCILITE 2014: The Rhetoric and Reality: Critical perspectives on educational technology, Dunedin.

Nassuora, A. B. (2012). Students' acceptance of mobile learning for higher education in Saudi Arabia. American Academic \& Scholarly Research Journal, 4(2), 24-30.

Ng, S. F., Confessore, G. J., Zulkarnain, Y., Aidil, N. A. A., Norhaini, M. L. (2011). Learner Autonomy and Academic Performance among Undergraduate Students. International Journal of Social Sciences \& Education, 1(4).

Nguyen, C. (2018). Demographic factors, family background and prior self-employment on entrepreneurial intention-Vietnamese business students are different: why? Journal of Global Entrepreneurship Research, 8(1), 10.

Nordin, N., Norman, H., \& Embi, M. A. (2015). Technology Acceptance of Massive Open Online Courses in Malaysia. Malaysian Journal of Distance Education, 17(2), 1-16.

Othman, M. N., Yap, S. F., \& Wee, Y. G. (2011). Examining the relationship between gender, age, education level and social cognitive factors in a health setting. International Journal of Business and Management, 6(9), 79.

Persada, S. F., Miraja, B. A., \& Nadlifatin, R. (2019). Understanding the generation Z behavior on D-learning: A Unified Theory of Acceptance and Use of Technology (UTAUT) approach. International Journal of Emerging Technologies in Learning (iJET), 14(05), 20 33.

Phang, C. W., Sutanto, J., Kankanhalli, A., Li, Y., Tan, B. C., \& Teo, H. H. (2006). Senior citizens' acceptance of information systems: A study in the context of e-government services. IEEE transactions on engineering management, 53(4), 555-569.

Plude, D. J., \& Hoyer, W. J. (1986). Age and the selectivity of visual information processing. Psychology and Aging, 1(1), 4. 
Puspitasari, N., Firdaus, M. B., Haris, C. A., \& Setyadi, H. J. (2019). An application of the UTAUT model for analysis of adoption of integrated license service information system. Procedia Computer Science, 161, 57-65.

Pynoo, B., Devolder, P., Tondeur, J., Van Braak, J., Duyck, W., \& Duyck, P. (2011). Predicting secondary school teachers' acceptance and use of a digital learning environment: A cross-sectional study. Computers in Human behavior, 27(1), 568-575.

Reid, G. (2005). Learning styles and inclusion. Sage.

Sánchez-Torres, J. A., Varon-Sandobal, A., \& Sánchez-Alzate, J. A. (2017). Differences between e-commerce buyers and non-buyers in Colombia: The moderating effect of educational level and socioeconomic status on electronic purchase intention. Dyna, 84(202), 175189.

Sime, D., \& Priestley, M. (2005). Student teachers' first reflections on information and communications technology and classroom learning: implications for initial teacher education. Journal of Computer Assisted Learning, 21, 130-142.

Stoszkowski, J., \& McCarthy, L. (2018). " Who Wouldn't Want to Take Charge of their Learning?" Student Views on Learner Autonomy, Self-Determination and Motivation. Journal of Perspectives in Applied Academic Practice, 6(2).

Sung, Y. T., Chang, K. E., \& Liu, T. C. (2016). The effects of integrating mobile devices with teaching and learning on students' learning performance: A meta-analysis and research synthesis. Computers \& Education, 94, 252-275.

Surjanti, J., Aji, T. S., Rahman, Z., \& Musfidah, H. (2019). Gender and Educational Background: Influence on Entrepreneurial Intention (EI) in Economics Learning. International Journal of Evaluation and Research in Education, 8(4), 604-609.

Tan, P. J. B. (2013). Applying the UTAUT to understand factors affecting the use of English elearning websites in Taiwan. Sage Open, 3(4), 2158244013503837.

Teo, T., \& Noyes, J. (2011). An assessment of the influence of perceived enjoyment and attitude on the intention to use technology among pre-service teachers: A structural equation modeling approach. Computers \& education, 57(2), 1645-1653.

Thomas, T., Singh, L., \& Gaffar, K. (2013). The utility of the UTAUT model in explaining mobile learning adoption in higher education in Guyana. International Journal of Education and Development using ICT, 9(3).

Turker, D., \& Selcuk, S. S. (2009). Which factors affect entrepreneurial intention of university students? Journal of European industrial training.

Van Zwanenberg, N., Wilkinson, L. J., \& Anderson, A. (2000). Felder and Silverman's Index of Learning Styles and Honey and Mumford's Learning Styles Questionnaire: how do they compare and do they predict academic performance? Educational Psychology, 20(3), 365-380.

Venkatesh, V., \& Davis, F. D. (2000). A theoretical extension of the technology acceptance model: Four longitudinal field studies. Management science, 46(2), 186-204.

Venkatesh, V., Morris, M. G., Davis, G. B., \& Davis, F. D. (2003). User acceptance of information technology: Toward a unified view. MIS quarterly, 425-478.

Venkatesh, V., Thong, J. Y., \& Xu, X. (2012). Consumer acceptance and use of information technology: extending the unified theory of acceptance and use of technology. MIS quarterly, 36(1), 157-178.

Wahi, W., \& Idris, F. (2017). Pendekatan heutagogi dalam pendidikan citra UKM abad ke -21. http://icerd2017.conference.upi.edu/download/ 
Wang, Y. S., \& Shih, Y. W. (2009). Why do people use information kiosks? A validation of the Unified Theory of Acceptance and Use of Technology. Government information quarterly, 26(1), 158-165.

Weng, F., Ho, H. J., Yang, R. J., \& Weng, C. H. (2019). The influence of learning style on learning attitude with multimedia teaching materials. Eurasia Journal of Mathematics Science and Technology Education, 15(1), 1-9.

Wong, K. T., Hwang, G. J., Goh, P. S. C., \& Ariff, S. K. M. (2018). Effects of blended learning pedagogical practices on students' motivation and autonomy for the teaching of short stories in upper secondary English. Interactive Learning Environments, 1-14.

Wong, K. T., Muhammad, M. @ M., Abdullah, N., \& Hamdan, A. (2020). Mobile-Heutagogical Practices among Student Teachers: Its Pedagogical Affordances and Challenges. International Journal of Interactive Mobile Technologies (iJIM), 14(02), 130143.

Wong, S. L., \& Teo, T. (2009). Investigating the technology acceptance among student teachers in Malaysia: An application of the technology acceptance model (TAM). AsiaPacific Education Researcher, 18(2), 261-272.

$\mathrm{Wu}, \mathrm{B} ., \quad \&$ Chen, X. (2016). Continuance intention to use MOOCs: Integrating the technology acceptance model (TAM) and task technology fit (TTF) model. Computers in Human Behavior, 67, 221-232.

Yeap, J. A., Ramayah, T., \& Soto-Acosta, P. (2016). Factors propelling the adoption of mlearning among students in higher education. Electronic Markets, 26(4), 323-338.

Yusoff, A. N. M., Mohammad R., Ali, N., \& Aziz, S. A. (2018). ID NO. UPM002 TOPIC: Memperkasakan Gamifikasi Dalam Hieps 4.0 Mpu Via 'Tools' Heutagogi, UNIVERSITY CARNIVAL on e-LEARNING (IUCEL) 2018. 389.

Zandi, G., Naysary, B., \& Say, S. O. K. (2013). The Behavioural Intention. Accounting and Management Information Systems, 12(3), 471.

Zhang, M., Liu, Y., Yan, W., \& Zhang, Y. (2016). Users' continuance intention of virtual learning community services: The moderating role of usage experience. Interactive Learning Environments, 1-19. http://doi.org/10.1080/10494820.2016.1172242 